\title{
The Factors Correlated with the Number of Floor Germ in Nursing Room of Banyumanik Hospital, Semarang in 2007
}

\section{Nurina Susanti Listyawati ${ }^{1}$ and Yusniar Hanani Darundiati ${ }^{2}$ \\ ${ }^{1}$ Postgraduate Student Faculty of Public Health, Universitas Indonesia, Depok, Indonesia \\ ${ }^{2}$ Department of Public Health, University Of Diponegoro, Semarang, Indonesia}

\section{Abstract}

Hospital as health care facilities also applies sanitation principle. One of the duty is to keep the floor cleanliness of the nursing room. The floor cleanliness level could be measured by the number of floor germ. The standard of the number of floor bacteria for the nursing room based on Kepmenkes No. 1204/MENKES/SK/X/2004 is $5-10$ colonies $/ \mathrm{cm}^{2}$. This research aimed to determine factors correlated with the number of floor germ of the nursing room in Banyumanik Hospital, Semarang, in 2007. This research was critical research with cross-sectional approach. The sample of this research was 15 rooms from totally 18 rooms. Correlation test used a Pearson Correlation for standard distribution data such as the room's temperature, room's lighting, and the result of waste. Spearman Correlation test used for abnormal distribution data such as the number of patients, number of visitors and room's humidity. The resulst of this research showed: 1) average the number of germs was 20.43 colonies $/ \mathrm{cm}^{2}$; 2) the number of patients 25 people; 3) the number of visitors was 197 people; 4) the average of room's temperature was $30.71^{\circ} \mathrm{C}$; 5) the average of room's humidity was $70.26 \% \mathrm{Rh}$; 6) the standard of room's lighting was 58.37 lux, and 7) the result of waste was 37 grams. From all factors, there's only room's lighting that had a significant correlation with correlation coefficient $r=-0.802$ and significant $p=0.018(p<0.05)$, and the other factors did not have a substantial relationship. Room's lighting was below the quality standards; it was necessary to repair the lighting system in the nursing room.

Keywords: The number of floor germ; hospital; nursing room

\section{Introduction}

Hospital is a health care institution which organizes personal health services in the plenary (the Ministry of Health Republic of Indonesia 2014). Based on decree from the Minister of Health of Indonesia: Kepmenkes 1204/Menkes/SK/X/2004 regarding Requirements Environmental Health Hospital is that the hospital as a health-care facility, a gathering place for the sick and healthy people, a place of disease transmission and the 
allowance of the environmental pollution and health problems (Ministry of Health Republic of Indonesia 2004).

According to Sutomo (1996) in Environmental Health Aspects in Hospital, it is widely known that floor at nursing room that can also be a place for the growth of microorganism has been observed on the floor of the nursing room class II from several hospitals in Central Java. The number of germs can measure the floor cleanliness level in the hospital germs. According to Kepmenkes 1204/Menkes/SK/X/2004, the amount of floor germ in the nursing room is $5-10$ colonies $/ \mathrm{cm}^{2}$. Based on research has been done by Triyantoro et al. (2003) regarding the number of floor germ in a nursing room in Banyumas Hospital, it is known that the amount of floor germ is always not eligible.

Banyumanik Hospital is a private hospital located in the South region of Semarang, precisely located on the street Jalan Bina Remaja No. 61, Srondol Wetan, Banyumanik. By decree from Minister of Health of Indonesia number: HK.03.05/I/7774/2010, the hospital is categorized as a D-type hospital.. The hospital has over $1.890 \mathrm{~m}^{2}$ with a building area of over $1.560 \mathrm{~m}^{2}$. Banyumanik Hospital committed to organizing health services that promote patient safety and patient safety by always keeping the quality of care (RS. Banyumanik). The variety of hospital services can be provided by the cleanliness of the hospital environment, especially in the nursing room that serves as a recovery of the sick person. One indicator of cleansing is to look at the total number of floor germ in the place. This hospital in $\mathbf{2 0 0 7}$ has not provided data or inspection of the number of floor germ in the nursing room. This research aimed to describe the magnitude of the amounts of floor germ in the nursing room and find out the factors that may associate with some floor germ.

\section{Method}

This research is explanatory research, using observation method and cross-sectional approach. The population was the whole nursing rooms of Banyumanik Hospital, 18 rooms. Samples were taken only 15 places with a sampling technique using proportional sampling, which is three rooms of Flamboyan, two rooms of Dahlia, six rooms of Melati, and for Anggrek, Teratai, Bougenvil, Baby Room and Intensive room respectively taken according to the population is one room. This research conducted over one day.

The variables of this research were divided into two types namely the independent variable (the number of patients, the number of visitors, temperature, humidity, lighting, and results of waste from floor cleaning), while the dependent variable was the number of floor germ in the nursing room of Banyumanik Hospital. 
The instruments used were the floor swab to take a sample number of germ in the afternoon after second time floor cleaning (12:00 PM to 01:00 PM) and in the evening during second time visiting hours (05:30 to 06:30 PM). Calculation of floor germ using laboratory tests used a growth medium Plate Count Agar (PCA) with the results in colonies $/ \mathrm{cm}^{2}$. Laboratory tests was done in the Laboratory of STIKES HAKLI Semarang. Observation used to calculate the number of patients and the number of the visitor- additional data such as attendance lists of the visitor before they enter a room. Thermohygrometer used to measure temperature with the results in ${ }^{\circ} \mathrm{C}$ and humidity with the result in \% $\mathrm{RH}$. A digital lux meter was used to measure the room lighting with the results in lux. Measurement of temperature, humidity, and light was done for three times in the morning (08:00 to 09:00 AM), the afternoon (12:00 PM to 01:00 PM) and the evening (6:00 to 07:00 PM). Plastic bags and scales used to measure the weight of waste from floor cleaning in the nursing room. Implementation of the floor cleaning was done for two times a day at afternoon (01:00 PM) and the evening (07:30 PM).

\section{Results}

The research was conducted for one day in March 2007. Sampling was conducted on the floor germ as 2 points: 1 point in the middle of the room and 1 point on a corner near the door of the room. Sampling was done for two times that at the afternoon and the evening. The average of the number of floor germ in nursing rooms was 20.43 colonies $/ \mathrm{cm}^{2}$. With an average number of floor germ, the highest was in Melati room ( 27 colonies $\left./ \mathrm{cm}^{2}\right)$, and the lowest was in Anggrek room (12.3 colonies $\left./ \mathrm{cm}^{2}\right)$. The average number of floors germ in the afternoon was 11.93 colonies $/ \mathrm{cm}^{2}$, and the evening was 28.87 colonies $/ \mathrm{cm}^{2}$. The numberof floor germ in nursing rooms of Banyumanik Hospital exceeded the quality standard that was 5-10 colonies $/ \mathrm{cm}^{2}$.

Based on the research results in the nursing room of Banyumanik Hospital, the number of patient was 25 people, the number of visitors was197 people, the average of the room's temperature was $30.71^{\circ} \mathrm{C}$, the proportion of the room's humidity was $70.26 \% \mathrm{Rh}$, the result of waste was $37 \mathrm{grams}$, and the average of the room's lighting was 58.37 lux.

From the results of data normality test using the ratio of Skewness and Kurtosis ratio is known that normally distributed variable is weight of waste, temperature, lighting, and the number of germs that for further processing these variables using Pearson correlation, whereas for a variable that is not normal to continue using Spearman correlation, according to Sugiyono (2003).

Based on the Pearson Correlation test, it was known that the relationship between the number of floor germ and lighting (coefficient $r=-0.802$ ), showing that increased 
TABLE 1: Data Normality Test Results.

Variables
Number of patients
Number of visitors
The weight of waste form floor cleaning
Room's temperature
Room's humidity
Room's lighting
Number of floor germ

\begin{tabular}{|c|c|}
\hline $\begin{array}{c}\text { Ratio of } \\
\text { Skewness }\end{array}$ & $\begin{array}{c}\text { Ratio of } \\
\text { Kurtosis }\end{array}$ \\
\hline 2.838 & 1.632 \\
\hline 3.607 & 5.785 \\
\hline 0.155 & -1.502 \\
\hline-1.641 & -1.502 \\
\hline-0.946 & 0.471 \\
\hline 0.260 & 3.331 \\
\hline-0.852 & -0.57 \\
\hline
\end{tabular}

\begin{tabular}{|c|}
$\begin{array}{c}\text { Normality } \\
\text { Test }\end{array}$ \\
Abnormal \\
\hline Abnormal \\
\hline Normal \\
\hline Normal \\
\hline Abnormal \\
\hline Normal \\
\hline Normal
\end{tabular}

TABLE 2: The Result of Pearson Correlation Test for Room's Lighting, Room's Temperature and Weight of Waste with Number of Floor Germ.

\begin{tabular}{|l|l|c|}
\hline Variables & Coefficient & $\begin{array}{c}\text { Number of Floor } \\
\text { Germ }\end{array}$ \\
\hline Room's lighting & Pearson Correlation & -0.802 \\
\hline \multirow{2}{*}{ Room's temperature } & Sig (2-tailed) & 0.018 \\
\hline \multirow{2}{*}{ The weight of waste form floor cleaning } & Pearson Correlation & 0.199 \\
\cline { 2 - 3 } & Sig (2-tailed) & 0.477 \\
\cline { 2 - 3 } & Pearson Correlation & 0.045 \\
\hline
\end{tabular}

exposure would cause a decrease in the name of floor germ and vice versa. The significant value of $p=0.018(p<0.05)$ showed that the change in the number of germ floor was significantly affected by the lighting of the room.

Results of the correlation test between the temperature with the number of floor germ showed a correlation coefficient $r=0.199$, showing that an increase in temperature would cause an increasing number of floor germ and vice versa. The significant value of $p=0.477$ ( $p>0.05$ ) showed that the change in the amount of floor germ was not significantly affected by temperature. Additionally, in this research, unknown types of bacterium were found on the floor in the nursing room belonged turmoil, mesophyll or Profile. Term life could be affected by changes in pressure, osmosis, light, acidity, and chemicals (Dwidjoseputro 1984).

Results of the correlation test between the weight of waste from floor cleaning with the number of floor germ showed a correlation coefficient $r=0.04$, showing that the increased weight of debris would cause an increase in the numbers of floor germ and vice versa. The significant value of $p=0.874$ ( $p>0.05)$ showed that the change in the amount of floor germ was not significantly affected by the weight of waste. Also, there was the possibility about other factors that could affect as the effectiveness of the disinfectant. 
TABLE 3: The Result of the Spearman Correlation Test of Number of Patients, Number of Visitors and Room's Humidity with Number of Floor Germ.

\begin{tabular}{|l|l|c|} 
Variables & Coefficient & $\begin{array}{c}\text { Number of Floor } \\
\text { Germ }\end{array}$ \\
\hline Number of patients & Pearson Correlation & 0.023 \\
\cline { 2 - 3 } Number of visitors & Sig (2-tailed) & 0.934 \\
\cline { 2 - 3 } & Pearson Correlation & 0.057 \\
\hline Room's humidity & Sig (2-tailed) & 0.839 \\
\hline & Pearson Correlation & 0.076 \\
\hline & Sig (2-tailed) & 0.788 \\
\hline
\end{tabular}

Based on the Spearman Correlation test, it is known that the relationship between the number of patients with the amount of floor germ had correlation coefficient $\rho=$ 0.023 , showing that an increase in the number of patients would lead to an increasing number of germ floor and vice versa. The significant value of $p=0.934(p>0.05$ showed the change in the amount of floor germ was not significantly affected by the number of patients. The possibility of microorganisms that exist was not from the patient.

Results of the correlation test between the number of visitors to the amount of floor germ showed the correlation coefficient $\rho=0.057$, showing that an increase in the number of visitors would lead to an increasing number of floor germ and vice versa. The significant value of $p=0.839(p>0.05)$ showed the change in the amount of floor germ was not significantly affected by the number of visitors. Moreover, it could cause way to clean floors that were less precise. At the observation, floor cleaning was being done during visitor's hours at 11.30 AM. Additionally, the corner did not come clean. Meanwhile, the curve was one of point sampling.

Results of the correlation test between humidity and the number of floor germ showed a correlation coefficient $\rho=0.076$, showing that increased moisture would cause an increasing number of floor germ and vice versa. The significant value of $p=0.788(p>$ 0.05 ) showed the change in some floor germ was not significantly affected by humidity. Also, there was the possible influence of other factors that were not investigated such as ventilation, making it unknown that the ventilation condition was already qualified or not.

\section{Discussion}

The number of floor germ in the nursing room of Banyumanik Hospital was 20.43 colonies $/ \mathrm{cm}^{2}$; it exceeds the standard. The amount of floor germ was influenced by various factors such as the number of patients, the number of visitors, room's temperature, room's humidity, room's lighting, result of waste, floor cleaning frequency 
and use of appropriate disinfectants (Triyanto et al. 2003). There was a difference with other research had been done by Wulandari et al. (2014) in the nursing room of PKU Muhammadiyah Yogyakarta Hospital for seven days, showing that the number of floor germ was below the standard (ten colonies $/ \mathrm{cm}^{2}$ ). It could be influenced by proper sanitation in the hospital (Wulandari et al. 2014).

Based on the research results on the nursing room of Banyumanik Hospital, there was the only nursing room with an average of the room's lighting (58.37 lux) that had a significant correlation. Based on Kepmenkes 1204/Menkes/SK/X/2004 the nursing room must have good lighting with a moderate light color, and it's a range of 100-200 lux at the morning, the afternoon and the evening and 50 lux at the night (Ministry of Health Republic of Indonesia 2004). The illumination less may result in an activity run less effective and uninterrupted patient comfort. Wards should get enough sunlight because sunlight has the effect of ultraviolet disinfection because of the sun rays of 295-400 nm (Irianto 2006).

There were differences with the research that had been done by Triyantoro et al. (2003), showing that in addition to the lighting, what associated with the number of floor germ was the weight of waste as a dominant factor (Triyantoro et al. 2003). Waste form nursing room of hospital could be considered as a chain of spread of infectious diseases. Dust in the waste could cause air pollution and the range of germ (Department of Health Republic of Indonesia 1992). It was also different from other research done by Wulandari et al. (2014) showing the number of visitors had the real correlation with the amount of floor germ. It was influenced by the activities undertaken by visitors in the room such as walking that could leave the microorganisms on the floor. Visitors potentially carried microorganisms from the outside (Wulandari et al. 2014).

The differences with the results of these two types of research may be due to the differences of the location of the hospital, the principles of sanitation performed at each hospital, times of research (year), and sampling period.

\section{Conclusion}

The results showed that the average total number of floor germs in the nursing room of Banyumanik Hospital was 20.43 colonies $/ \mathrm{cm}^{2}$ and that number was over the standards specified in Kepmenkes 1204/Menkes/SK/X/2004. From all factors, there's only room's lighting that had a significant correlation with correlation coefficient $r=-0.802$ and significant $p=0.018(p<0.05)$. The average room's light on the nursing room was 58.37 lux, and this number was below the standard. 
Suggestions for the managerial of Banyumanik Hospital, it was necessary to control the physical environment of space periodic and continuous care for once in 6 months for lighting, temperature, humidity, ventilation, pressure and bacteriological condition of the floor, walls, and air. It was also needed to increase the intensity of illumination in the room that had lower lighting intensity by giving additional lights or maximize natural light with the use of glass tiles.

\section{References}

[1] Department of Health Republic of Indonesia. 1992. Pedoman Sanitasi Rumah Sakit di Indonesia. Jakarta: Ditjen PPM dan PLP Departemen Kesehatan. http://www.perpustakaan.depkes.go.id/cgi-bin/koha/opac-detail.pl?biblionumber= 1438\&shelfbrowse_itemnumber=2731 (accessed October 30, 2016)

[2] Dwidjoseputro D. 1984. Dasar-dasar Mikrobiologi. Jakarta: Djambatan.

[3] Irianto, Koes. 2006. Mikrobiologi Menguak Dunia Mikroorganisme Jilid 1. Bandung: CV Yrama Widya.

[4] Ministry of Health Republic of Indonesia. 2004. Persyaratan Kesehatan Lingkungan Rumah Sakit. Keputusan Menteri kesehatan RI nomor 1204/Menkes/SK/X/2004.

[5] Ministry of Health Republic of Indonesia. 2014. Klasifikasi dan Perizinan Rumah Sakit. Peraturan Menteri Kesehatan nomor 56 tahun 2014.

[6] RS Banyumanik. Profil Rumah Sakit Banyumanik. http://rsbanyumanik.com/profil/ (accessed October 25, 2016).

[7] Sugiyono. 2003. Statistika Untuk Penelitian. Bandung: CV Alfabeta.

[8] Sutomo, A.H. 1996. Aspek Kesehatan Lingkungan Di Rumah Sakit, Bagian IImu Kesehatan Masyarakat, Fakultas Kedokteran UGM, Yogyakarta, Unpublished Library Book of Medical Faculty of GMU.

[9] Triyantoro Budi, Sarto and Agus Suwarni. 2003. "Faktor-Faktor Penentu Angka Kuman Lantai Ruang Perawatan Dahlia RSU Banyumas". Sains Kesehatan 16 (3).

[10] Wulandari Windi, Adi heru Sutomo, and Susi Irawati. 2014. "Angka Kuman Udara dan Lantai Ruang Rawat Inap Rumah Sakit PKU Muhammadiyah Yogyakarta”. Jurnal Berkala Kesehatan Vol. 1 No. 1. 2015. http://ppjp.unlam.ac.id/journal/index.php/berkala-kesehatan/article/view/655 (accessed October 20, 2016) 